\title{
Corrective derotation osteotomies to treat congenital radioulnar synostosis in children: results of a systematic review and meta-analysis.
}

Sandeep Kumar Nema ( $\sim$ drsandeepnema@gmail.com )

JIPMER Pondicherry https://orcid.org/0000-0002-0254-3944

Premkumar Ramasubramani

Jawaharlal Institute of Postgraduate Medical Education: Jawaharlal Institute of Postgraduate Medical Education and Research

Pasupathy Palaniappan

Jawaharlal Institute of Postgraduate Medical Education: Jawaharlal Institute of Postgraduate Medical Education and Research

Jose Austine

Jawaharlal Institute of Postgraduate Medical Education: Jawaharlal Institute of Postgraduate Medical Education and Research

\section{Research Article}

Keywords: Congenital, congenital proximal radioulnar synostosis, rotation osteotomy, children, elbow anomaly, subjective evaluation, objective evaluation, osteotomy, complications, follow-up.

Posted Date: February 16th, 2022

DOI: https://doi.org/10.21203/rs.3.rs-816066/v1

License: @ (i) This work is licensed under a Creative Commons Attribution 4.0 International License. Read Full License

Version of Record: A version of this preprint was published at Indian Journal of Orthopaedics on January 21st, 2022. See the published version at https://doi.org/10.1007/s43465-021-00582-4. 


\section{Abstract \\ Background}

The primary objective of this review is to estimate the rotational correction after corrective derotation osteotomies (CDO) for Congenital radioulnar synostosis (CRUS). The secondary objective of this review is to identify the complications with CDO in CRUS,

\section{Methods}

We included studies in the English literature from electronic bibliographic databases Cochrane Central Register of Controlled Trials (CENTRAL), CINAHL, Directory of Open access journals (DOAJ), EMBASE, MEDLINE, ProQuest, PubMed, and Scopus up to December 2020 that determined the effects of CDO in CRUS for two or more cases with a mean follow-up of 1 year or more. We used the National Institutes of health quality assessment tool for case series (interventional) and Modified Coleman methodology Score for assessment of Risk of bias in the included studies.

\section{Results}

We pooled 383 forearms (318 participants) from 23 studies with mean age of $6.28 \pm 1.75$ years. The mean pronation deformity was $72.83 \pm 15.64^{0}$ from 22 studies. The CDO derotated forearm to $10.4 \pm 5.90^{\circ}$ of mean pronation in 12 studies and $13.47 \pm 9.51^{0}$ of mean supination in 9 studies. One study corrected the forearms to a neutral position. The mean derotation from CDO was $73.13 \pm 16.54^{0}$ ( $35^{0}$ supination to $130^{0}$ pronation). The overall mean difference was $-68.26^{0}$ [95\% Cl-86.87, -49.66] of correction favouring supination. There were eight transient nerve palsies and six compartment syndromes from synostosis site osteotomies (4 studies).

\section{Discussion}

We had poor-quality studies at a High Risk of bias on the described tools of assessment. We could estimate the directional effect of CDO in CRUS favouring correction from pronation to supination; however, due to the heterogeneity among studies, we cannot comment on the most efficient and least harmful CDO techniques. The single bone osteotomies seem to be efficient, simple, and reportedly low on complications but need evaluation. We cannot define the indications for correction and expected improvement in functional outcomes from osteotomy techniques.

\section{Introduction}

Congenital radioulnar synostosis (CRUS) is a skeletal anomaly due to the failure of prenatal longitudinal segmentation at the proximal radius and the ulna. A fibrous or bony bridge of variable length between the radius and ulna causes limitation in forearm rotation (1). The forearm deformity ranges from neutral to marked pronation in CRUS. The functional disability is dependent on the severity of fixed forearm rotation, bilaterality, and the prevalent cultural and social practices (2). Therefore, there is considerable variation in the indications for any operation in CRUS. Synostosis resection and mobilization with or without interposition and corrective derotation osteotomies (CDO) are the two management options in CRUS $(1,3)$. The former relies on giving a mobile proximal radioulnar joint (Kanaya procedure being the prototype), while the latter attempts to place the forearm in a more suitable position by osteotomising one or both forearm bones $(3,4)$. Recently reverse Sauvé- Kapandji procedure and llizarov mediated correction have reported variable success in CRUS treatment $(3$, 5). Non-operative management is usually reserved for one or both sides, depending on the limitation in the activities of daily living (ADL). The CDO gained favour in the late 1990s because of unpredictable outcomes with synostosis excision (1). There is considerable heterogeneity among published series for the optimum age and the osteotomy site for $\operatorname{CDO}(1,4,6,7)$. The number of bones for osteotomy and the need for implant fixation in CDO are also variable $(2,6,7)$. There is a marked variation in the complications with various $C D O$ techniques $(2,4,8-11)$. The primary objective of this review is to estimate the rotational correction achieved by CDO in CRUS. The secondary objective of this review is to identify the complications with CDO in CRUS,

\section{Material And Methods}

The procedures followed in this review were per the ethical standards of the responsible committee on human experimentation (institutional and national). We conducted this review following guidelines in the preferred reporting items for the systematic review and meta-analysis (PRISMA) (12).

\section{Eligibility Criteria (Inclusion criteria and exclusion criteria)}

We included studies/reports published in English literature that determined effects of CDO in CRUS for two or more cases with a mean follow-up of 1 year or more. This included Children, skeletally immature adolescents (typically aged under 16 years), and adults with CRUS. The studies were included irrespective of the osteotomy site in the forearm, the number of osteotomized bones, and the immobilization method (plaster cast, plates, and screws, and pins (transverse, crossed, or intramedullary). We excluded studies that assessed the effects of interventions in radioulnar synostosis following trauma. Reports that described syndromic associations with CRUS without reporting the results of interventions were excluded. We excluded animal, cadaveric, and radiologic studies. We did not include reports that assessed synostosis resection and reconstruction (Kanaya procedure and its modifications), reverse Sauve Kapandji procedure, and Ilizarov mediated correction in CRUS $(3,5)$. While we excluded the studies described above, this review included CDO cases from mixed studies that used more than one intervention for CRUS $(13,14)$.

\section{Information sources}


We searched the electronic literature to identify studies in the English language up to November 2020 on CRUS. We searched Cochrane Central Register of Controlled Trials (CENTRAL) (2020 issue 12), CINAHL (1984 to December 2020), Directory of Open access journals (DOAJ) (December 2020), EMBASE (1974 to December 2020), MEDLINE (1946 to December 2020), ProQuest (1990 to December 2020), PubMed (1952 to December 2020) and Scopus (1930 to December 2020) for studies on CRUS.

Search Strategy: Appendix 1 describes the search strategy for the electronic databases for this review.

\section{Searching other resources}

We searched the references from the included studies on CRUS. We excluded conference proceedings, books, and dissertations on CRUS.

\section{Selection of studies and data collection process}

Review authors SN and PP independently screened all titles and abstracts for potentially eligible studies. We obtained full-text reports where appropriate. The same two review authors independently performed study selection. We resolved any disagreements about the inclusion or exclusion of individual studies and data extraction either by discussion between the two authors or with the involvement of another review author (JA). We did not contact the authors of included studies. The data collected had information on study design, study population, interventions, outcomes measures, and results. All three review authors discussed and decided on the final study selection to ensure a consensus. We did not mask the source and authorship of the trial reports. Review authors (P) entered initial data into Review Manager 5.

We identified the data from the text and tables of the isolated studies. We preferred estimation of outcomes from tables in isolated case series.

Data Items (outcome measures): 1. Average rotational deformity of forearm before and after CDO. 2. The correction/derotation achieved in the forearm. 3 . Physical function using validated measures, such as the classification system established by Failla et al. for 15 tasks described by Morrey et al., or Jebson and Taylor hand function test, Liverpool elbow score, disability of shoulder elbow and hand- Quick DASH $(2,10,11,16) 4$. Loss of correction greater than 5 degrees, the presence of symptomatic malunion/unacceptable (deformity), 5. Serious adverse events: Infection, nerve or tendon injury, compartment syndrome, refracture.

\section{Assessment of Risk of bias in included studies}

Pairs of the same review authors performed independent 'Risk of bias assessment of the included trials. We used 'The National Institutes of Health (NIH) quality assessment tool for case-series (Interventional)' and Modified Coleman methodology Score for 'Risk of bias assessment in this review (17, 18). The $\mathrm{NIH}$ quality assessment tool analyses the study/case series on nine questions to determine the study's methodological quality. We modified the scale; the responses of yes and no were assigned integers 1and 2 for each question. However, the response of cannot Determine/ Not Applicable/ Not Reported was not assigned. The summated scores from 9 domains of each study ranged from 0 to 18 . To assess the study quality, they were rated poor, fair, and good based on their score less than <25th, 25 to 75, and > 75th percentile, respectively. Modified Coleman methodology score (CMS) is a Risk of bias assessment tool that uses ten domains, with a total score between 0 and 100. A score of 100 indicates that the study largely avoids chance, various biases, and confounding factors. The subdomains that make up the CMS are based on the subsections of the Consolidated Standards of Reporting Trials (CONSORT) statement (for randomized controlled trials) and are modified to allow for other trials.

\section{Statistical analysis:}

Effect measures. Meta-analysis of the included studies was done using Review Manager 5.4. The rotational deformity of the forearm from the studies was pooled with a random-effects model. The estimation of heterogeneity and inconsistency across included studies was done using the Chi-square test and $\mathrm{I}^{2}$ statistics. The pooled estimate of the rotational deformity was graphically represented with a forest plot. A subgroup analysis was done to estimate the difference in correction/derotation among different osteotomy techniques, immobilization methods. We performed descriptive analysis using means, SD, and ranges (minimum and maximum) of the pooled data across the included studies. Software STATA version14 was used for the analysis.

\section{Results}

Results of search (study selection):

We searched 4604 records up to December 2020 on CRUS from electronic databases Cochrane Central Register of Controlled Trials (CENTRAL) (0), CINAHL (114), DOAJ (162), Embase (724), Medline (703), Proquest (863), Pubmed (1625), and Scopus (413). We isolated 19 studies meeting the inclusion criteria from electronic databases $(2,4,6-11,13,14,16,19-26)$. Another four studies were isolated from the references of the isolated studies (27-30). We assessed 23 studies in qualitative and quantitative analysis. There were four prospective and 16 retrospective studies/case series included for assessment in this review. Three studies did not specify the nature of the study. Figure 1 is the PRISMA diagram for the studies in this review.

Study characteristics. The characteristics of included studies are presented in Table 1.

Risk of Bias in the included studies: Table 2 presents the Risk of bias assessment for this review. We found that all reports were either prospective or retrospective case series with high-Risk of bias. We had four studies, each rated good and poor while 15 reports fair on the Risk of bias assessment with the $\mathrm{NIH}$ tool for this review. Figure 2 presents the Risk of bias assessment on the NIH assessment tool for this review. The mean score from the modified Coleman methodology for Risk of assessment of bias was $40.30 \pm 8.8$. The description of Surgical technique and follow-up domains scored high across all studies; however, the reports were rated poor on sample size (number of forearms operated), description of outcome criteria, and procedure of assessing outcomes. 
The studies uniformly described the mean deformity before and after CDO; however, functional outcomes on a measurable scale were reported by five studies $(2,10,11,16,23)$.

Demographic outcomes: There were 4 studies each from Europe $(14,20,25,26)$, America $(4,6,8,13)$, and Africa $(19,21,29,30)$. There were 11 studies from Asia $(2$, $7,9-11,16,22-24,27,28)$. We identified 383 forearms/318 participants from 23 studies on CDO for CRUS. There were 114 right, 98 left, and 112 bilateral forearms with CRUS. Nine studies described hand dominance $(2,11,13,19,20-24)$. There were 189 males and 129 females. The mean age of the participants at CDO was $6.28 \pm 1.75$ years, ranging from 2 to 22 years $(10,13,30)$. There were five classification schemes from 15 studies for CRUS in this review $(1,22,26$,

$37,38)$. The classification schemes for CRUS are based on the shape, position of the radial head in the elbow joint, and the radiographic pattern of synostosis (Table 3). Twelve studies classified 4, 25, 152, and 5 forearms under Cleary and Omer types I II III and IV, respectively (Table 1). Two studies classified patients as per the scheme reported by Tachdjian and Wilkie (Table 1), while another study devised a new classification for identifying patients (26). The mean followup after CDO was $66.81 \pm 48.73$ ( 6 to 312 ) months. The mean time to union was $7.27 \pm 1.67$ weeks (4 to 16 weeks).

Primary outcomes from the included studies: The mean preoperative pronation deformity was $72.83 \pm 15.64^{0}\left(62.92^{0}\right.$ to $\left.82^{\circ}\right)$ from 22 studies $(2,4,6-11,13$, $14,18-21,23-30)$. The postoperative deformity after CDO was reported by 22 Studies. Twelve studies $(4,8,13,14,18-21,23,26,29,30)$ corrected the forearm to a mean pronation deformity of $10.4 \pm 5.9^{0}\left(3^{0}\right.$ to $\left.22^{0}\right)$ degrees, while nine studies $(2,6,9-11,24,25,27,28)$ corrected the forearm to a mean supination deformity of $13.47 \pm 9.51^{0}\left(4.2^{0}\right.$ to $\left.27.2^{0}\right)$. One study corrected the forearms to a neutral position (7). The mean correction achieved was $73.13 \pm 16.54^{0}\left(35^{0}\right.$ supination to $130^{\circ}$ pronation). The correction achieved and the pooled mean difference between the deformity before and after CDO is presented in Figure 3 . The overall mean difference was $-68.26[95 \% \mathrm{Cl}-86.87,-49.66]$. The mean difference shows correction favouring supination. We got an $\mathrm{I}^{2}$ index of $100 \%$, depicting significant heterogeneity among the studies. The pooled effect estimate was calculated with the random-effects model.

Secondary outcomes from the included studies: Six studies used plaster of Paris splint after CDO for immobilization $(2,7,13,16,21,22)$. Fifteen studies used various metallic fixation devices for osteotomy site fixation $(4,6,9-11,14,19,20,23-25,26,28-30)$. Two studies were heterogeneous on the mode of immobilization, which included plaster of Paris splint and implant both and hence were not included in comparison $(8,27)$. Five studies used long intramedullary wire/ nail for CDO fixation $(11,19,23-25)$. Six studies used crossed $\mathrm{K}$ wire for osteotomy fixation $(4,6,14,21,28,29)$. One study used tension band wire (9). Two studies each used Plate fixation $(10,30)$ and heterogeneous methods for CDO fixation $(8,26)$. One study compared plaster of Paris and intramedullary fixations in both bone double level CDO (11). Overall, there were 22 incidents of significant loss of correction (>5 degrees) after CDO (Table 4 ). There were 11 incidents each of loss of correction in plaster of Paris splint and implant fixation groups. Six forearms had a loss of correction where intramedullary wires were used for CDO fixation $(23,24)$. There were two incidents of loss of correction among plate fixations $(26)$ and one each among crossed K wires (29), staple (8), and external fixation (26). We classified the studies into three osteotomy types based on the osteotomy location and number of bones osteotomised in the forearm: 1 . There were seven studies ( 112 forearms) that osteotomised synostosis site to achieve desired correction ( $4,6,9,10$, $20,29,30)$ 2. Nine studies (163 forearms) osteotomised the forearm bones at different levels to achieve the desired derotation of the forearm $(2,11,13,19,21$, $23-25,26) 3$. However, four studies (54 forearms) osteotomised one of the forearm bones for correction of deformity (radius three studies and ulna 1 study) $(7,16,22,28)$. Three heterogeneous studies (54 forearms) used more than one osteotomy technique described above to derotate the forearm in the desired correction $(8,14,27)$. We did pooled estimate for each of the subgroups of osteotomies (Supplementary material 1$)$.

Neurovascular complications and compartment syndrome dominated complications in CDO for CRUS. In this review, four studies of synostosis site osteotomy recorded eight transient/reversible nerve palsies and six incidents of compartment syndrome/muscle herniation/circulatory compromise (4, 8-10). Another four incidents of compartment syndrome were reported by other studies $(6,25,28,29)$.

Functional outcomes in CDO: Four reports described functional outcomes in CDO by assessment scales/questionnaire (Table 1) $(2,10,11,16)$. The Liverpool Elbow Score, the classification system used by Failla et al., Jebsen-Taylor hand-function test, and quick disabilities of the arm, shoulder, and hand score (QuickDASH), described outcomes assessment tools. Significant improvements were recorded in the described assessment scales/questionnaire after CDO. Three studies devised novel scoring systems to assess functional improvements after $\operatorname{CDO}(6,8,23)$. Other studies evaluated the outcomes based on the parent and patient satisfaction in executing ADL after CDO.

\section{Discussion}

Overall, there is insufficient evidence from Prospective and Retrospective cases series/reports to determine the most appropriate osteotomy technique for treating CRUS in children and young adults. The search did not yield any high-quality studies (randomized and quasi-randomized controlled trials). The included studies were of poor quality with a High Risk of bias on the described tools for assessment. The reports described outcomes from a new or existing CDO technique in CRUS. Though all the studies described the extent of correction, the improvements in activities of daily living were poorly reported. There was considerable heterogeneity among the described osteotomy techniques to draw meaningful conclusions on functional outcomes after CDO. It may be in part due to the rarity of CRUS cases. We could estimate the directional effect of CDO in CRUS favouring correction from pronation to supination; however, given the reasons for the heterogeneity among studies, we cannot comment on the most efficient and least harmful CDO among three existing techniques statistically. We cannot define the optimum indications for correction and expected improvement in functional outcomes from osteotomy techniques. Likewise, we cannot comment on the frequency of a complication among osteotomy techniques due to poor study quality and variation among osteotomy techniques. The complications are reported sporadically across studies and the predicting factors for complications are not described. Single bone osteotomies appear to be efficient, simple, and reportedly low on complications The proximal osteotomies at the synostosis site increase the Risk of neurovascular complications due to extremes of rotation over a narrow segment in the forearm. Several authors have described indications for CDO in CRUS $(2,6,7,10,11,16)$. These indications range from the severity of forearm deformity to restriction of ADL. Recent studies recommend 10 to 20 degrees of supination for both dominant and non-dominant-sided CRUS due to the compensation by shoulder internal rotation and abduction for pronation (16). Functional outcome scores on Jebson and Taylor and Liverpool elbow score indicate operation indications in a few reports $(2,10,11,16)$. However, we could

Page $4 / 19$ 
not analyse them due to heterogeneity between the studies. We observed that a fixed supination deformity was seldom an indication for CDO except for bilateral involvement. Studies have proposed radiological classification schemes for defining indications for CDO, but they have poor clinical relevance (7). No difference in outcomes has been demonstrated in comparison among different radiological types. Three studies reported compensatory rotation from the wrist in pronosupination after $\operatorname{CDO}(9,16,22)$. However, there is no definite way to assess compensatory rotations from the elbow, wrist, and shoulders. Ramachandran et al. noted hypermobility of the wrist in all the cases (25).

We classified the studies into three types based on the location of the osteotomy site and the number of bones osteotomised in the forearm.

Both bones double-level osteotomies: The technique described by Server and Gibson involves osteotomy of both bones of the forearm by mini-incisions at the proximal ulna subcutaneous border, distal to the synostosis site, and distal radius at the diaphyseal-metaphyseal junction to derotate the forearm into the desired correction (2). Synostosis site osteotomy: The osteotomy at the synostosis site, as described by Green and Mital, is done by an incision at the subcutaneous border of the ulna proximally exposing the synostosis site after subperiosteal dissection. The forearm is then rotated to desired position (6).

Single bone osteotomies of the forearm: This osteotomy and its variations involve osteotomising either proximal ulna or distal radius at the diaphysealmetaphyseal junction to derotate the forearm in the desired position (7). The choice of implant for immobilization of the osteotomy site staged correction/derotation is variable across studies. All the described osteotomy techniques share the Risk of Neurovascular complications (NVC) due to extremes of rotation. The synostosis site osteotomies are at a higher risk of NVC due to extremes of rotation over a narrow segment. Both bones double-level osteotomy is our technique of choice for derotation in CRUS. However, we plan the incision and osteotomy cuts on true anteroposterior (AP) and lateral radiographs taking account of magnification. We draw an imaginary straight line connecting the Distal ulna and the proximal radius through the centre of the broadest part of the interosseous membrane on the AP radiograph [Figure 4]. The points of intersection of this imaginary line with the centre of the ulnar and radial medullary canal are chosen as reference for incision and the sites for osteotomy on the forearm bones [Figure 4].

To the best of our knowledge, the reasons for selecting one of the three osteotomies described in this paper have not been elaborated in the published series. The rationale behind the exact anatomical site in the osteotomy techniques has not been reported. We follow our described method for both bone osteotomy due to the following reasons: 1 . The anatomy of the radius is narrow and cylindrical proximally and broad, and trapezoid distally. The reverse holds for the ulna. Therefore, an osteotomy in the narrow and cylindrical part of these bones will have a lesser translation. 2. The mal-alignment close to the distal radioulnar joint is poorly tolerated because the radius must rotate in three planes for pronosupination around the ulnar head. 3 . The arc of rotation of the ulna close to the distal radioulnar joint is minimal. Therefore, any mal-alignment is well tolerated. 4. Poor healing of osteoclasis and fractures has been reported by few studies due to a relative watershed zone of the blood supply in the proximal ulna. (39-40). The points of intersection of the imaginary line though crude but provide a reproducible and consistent anatomical reference for osteotomy.

We found two reviews on the existing methods for the treatment of CRUS $(1,3)$. Barik et al. studied the correlation between age, proximal osteotomies, hardware, double level osteotomy, and loss of reduction among the existing CRUS treatment methods (1). However, they failed to include another 76 forearms from 6 studies $(2,26-30)$. Their review included one study which did not describe outcomes (36). They evaluated outcomes from the heterogeneous methods for CRUS treatment. We did not perform pooled data analysis to find a correlation between age and the osteotomy site in the forearm because of significant heterogeneity among the included studies. Another narrative review by Rutkowski et al. discussed the embryology, causation, classification pathophysiology, and management modes for CRUS (3). The optimum age for CDO is debatable in literature. However, several authors have recommended age between 3-6 years to be ideal for $\operatorname{CDO}(1,2,7,22,23)$. Operation at an early age is associated with a low risk of neurovascular complications $(7,23)$.

It is unlikely that the review process has introduced bias; however, we conducted a meta-analysis to estimate mean correction and deformity before and after CDO across the included studies in the forearm. We have reported the potential biases associated with the studies themselves. We believe that publication bias is unlikely; the search was extensive and included the bibliography across available electronic databases.

Though CRUS is a rare congenital anomaly, there is a need to establish the best treatment. Given the unpredictable outcomes with synostosis resection and the Risk of recurrence, $\mathrm{CDO}$ is a valuable alternative in placing the forearm position for useful function. The limited information on the indications for treatment, choice of CDO technique, fixation method, and treatment outcomes hampers meaningful conclusions. However, given the need for intervention after 60 degrees of fixed pronation deformity and limitation in activities of daily living, such patients appear to be suitable subjects for future randomized controlled trials $(7,23)$. All future research should meet robust contemporary standards of design, conduct, and reporting, including the use of randomisation methods involving stratification, to ensure baseline equivalence between treatment groups regarding type of synostosis, CDO, and outcomes measures.

Limitations of this review: Definite conclusions for practice cannot be drawn from this review, given the poor quality of included studies because there are no randomized or quasi-randomized controlled trials for $C D O$ in the treatment of CRUS. Heterogeneity among the included studies leads to weak evidence for the benefits and harms of the different osteotomy techniques.

\section{Conclusion}

Conclusion: We conclude that there is a directional effect of CDO in CRUS favouring correction from pronation to supination across all studies; however, the poor-quality studies on CDO preclude us from drawing meaningful conclusions on the most appropriate osteotomy technique. As per our literature review, single bone osteotomy techniques could be less invasive, efficient, and less harmful in the Risk of neurovascular complications for CRUS in children, but this observation needs good quality multicentre studies to substantiate our findings.

\section{Declaration}

Funding: 'Not applicable' 
Conflicts of interest/Competing interests: The authors declare no conflict of interest in the work submitted.

Availability of data and material: The data will be provided as supplementary material on demand and uploaded to Mendeley.

Authors' contributions

Author 1. Dr Sandeep Kumar Nema conducted the search, prepared the data collection proforma, and was one of the review authors, Dr Nema undertakes the responsibility as guarantor and corresponding author for the manuscript

Author 2. Dr Premkumar ramasubramani entered the data into the review manager, performed the statistical analysis and contributed for manuscript editing and preparation.

Author 3. Dr Pasupathy P contributed as one of the review authors and manuscript preparation and review

Author 4. Dr Jose Austine contributed as one of the review authors and manuscript preparation and review.

Acknowledgment: The authors acknowledge Dr. Sitanshu Kar, Professor Department of Preventive and Social Medicine School of Public health JIPMER

Pondicherry India, Dr. Suresh Gandhi B. Associate Professor Department of Orthopedics JIPMER Pondicherry India, for sharing his radiology based both bone forearm CDO technique for CRUS and Dr. Ruchin Agarwal Consultant Emergency Medicine NHS the UK for contributing towards the search of electronic databases

\section{References}

1. Barik, S., Farr, S., Gallone, G., Zarantonello, P., Trisolino, G., \& Di Gennaro, G. L.. Results after treatment of congenital radioulnar synostosis: a systematic review and pooled data analysis. J Pediatr Orthop B. 2021 Nov 1;30(6):593-600. doi: 10.1097/BPB.0000000000000841

2. Shingade, V. U., Shingade, R. V., \& Ughade, S. N. (2014 Jan). Results of single-staged rotational osteotomy in a child with congenital proximal radioulnar synostosis: subjective and objective evaluation. J Pediatr Orthop, 34(1), 63-69. doi: 10.1097/BPO.0b013e3182a00890.

3. Rutkowski, P. T., Samora, J. B.. Congenital Radioulnar Synostosis., Am Acad, J., \& Orthop Surg. (2021).. Jul 1;29(13):563-570. doi: 10.5435/JAAOS-D-2001133. PMID: 33826558. https://doi.org/10.5435/JAAOS-D-20-01133

4. Simcock, X., Shah, A. S., Waters, P. M., \& Bae, D. S. (2015 Dec). Safety and Efficacy of Derotational Osteotomy for Congenital Radioulnar Synostosis. J Pediatr Orthop, 35(8), 838-843. doi: 10.1097/BP0.0000000000000370.

5. Barrera-Ochoa, S., Campillo-Recio, D., \& Mir-Bullo, X. (2019 May). Treating bilateral congenital radioulnar synostosis using the reverse Sauvé-Kapandji procedure. J Hand Surg Eur Vol, 44(4), 430-432. doi: 10.1177/1753193419827853.. Epub 2019 Feb 18

6. Green, W. T., \& Mital, M. A. (1979 Jul). Congenital radio-ulnar synostosis: surgical treatment. J Bone Joint Surg Am, 61(5), 738-743. https://doi.org/10.2106/00004623-197961050-00015

7. Horii, E., Koh, S., Hattori, T., \& Otsuka, J. (2014 Aug;39(8):1553-7). Single osteotomy at the radial diaphysis for congenital radioulnar synostosis. J Hand Surg Am. doi: 10.1016/j.jhsa.2014.05.018. Epub 2014 Jul 2. PMID: 24996678. https://doi.org/10.1016/j.jhsa.2014.05.018

8. Simmons, B. P., Southmayd, W. W., \& Riseborough, E. J. (1983 Nov;8(6):829-38). Congenital radioulnar synostosis. J Hand Surg Am. doi: 10.1016/s03635023(83)80078-1. PMID: 6643957. https://doi.org/10.1016/S0363-5023(83)80078-1

9. Ogino, T., \& Hikino, K. (1987 Jun;12(2):173-8). Congenital radio-ulnar synostosis: compensatory rotation around the wrist and rotation osteotomy. J Hand Surg Br. doi: 10.1016/0266-7681(87)90006-4. Erratum in: J Hand Surg [Br] 1987 Oct;12(3):402

10. Pei, X., \& Han, J.. Efficacy and feasibility of proximal radioulnar derotational osteotomy and internal fixation for the treatment of congenital radioulnar synostosis.J Orthop Surg Res. 2019 Mar20;14(1):81. doi: 10.1186/s13018-019-1130-0

11. Hwang, J. H., Kim, H. W., Lee, D. H., Chung, J. H., \& Park, H. (2015 Oct). One-stage rotational osteotomy for congenital radioulnar synostosis. J Hand Surg Eur Vol, 40(8), 855-861. doi: 10.1177/1753193415580066.. Epub 2015 Mar 31

12. Page, M. J., McKenzie, J. E., Bossuyt, P. M., Boutron, I., Hoffmann, T. C., Mulrow, C. D., et al.. The PRISMA 2020 statement: an updated guideline for reporting systematic reviews.Syst Rev. 2021 Mar29;10(1):89. doi: 10.1186/s13643-021-01626-4

13. Lin, H. H., Strecker, W. B., Manske, P. R., Schoenecker, P. L., \& Seyer, D. M. (1995 Jan-Feb). A surgical technique of radioulnar osteoclasis to correct severe forearm rotation deformities. J Pediatr Orthop, 15(1), 53-58. doi: 10.1097/01241398-199501000-00012.

14. Khalil, I., \& Vizkelety, T. (1993). Osteotomy of the synostosis mass for the treatment of congenital radio-ulnar synostosis. Arch Orthop Trauma Surg, 113(1), 20-22. doi: 10.1007/BF00440589.

15. Failla, J. M., Amadio, P. C., \& Morrey, B. F. (1989 Sep). Post-traumatic proximal radio-ulnar synostosis. Results of surgical treatment. J Bone Joint Surg Am, 71(8), 1208-1213. 2777849.https://doi.org/10.2106/00004623-198971080-00014PMID:

16. Satake, H., Kanauchi, Y., Kashiwa, H., Ishigaki, D., Takahara, M., \& Takagi, M.. Long-term results after simple rotational osteotomy of the radius shaft for congenital radioulnar synostosis.J Shoulder Elbow Surg. 2018Aug;27(8):1373-1379. doi: 10.1016/j.jse.2018.04.012

17. Longo, U. G., Rizzello, G., Loppini, M., Locher, J., Buchmann, S., Maffulli, N., \& Denaro, V. (2015 Dec). Multidirectional Instability of the Shoulder: A Systematic Review. Arthroscopy, 31(12), 2431-2443. doi: 10.1016/j.arthro.2015.06.006.. Epub 2015 Jul 21

18. Ma, L. L., Wang, Y. Y., Yang, Z. H., Huang, D., Weng, H., \& Zeng, X. T.. Methodological quality (Risk of bias) assessment tools for primary and secondary medical studies: what are they and which is better?Mil Med Res. 2020 Feb29;7(1):7. doi: 10.1186/s40779-020-00238-8 
19. Bishay, S. N. (2016 Aug). Minimally invasive single-session double-level rotational osteotomy of the forearm bones to correct fixed pronation deformity in congenital proximal radioulnar synostosis. J Child Orthop, 10(4), 295-300. doi: 10.1007/s11832-016-0750-8.. Epub 2016 Jun 16

20. Castelló, J. R., Garro, L., \& Campo, M. (1996). Congenital radioulnar synostosis. Surgical correction by derotational osteotomy. Ann Chir Main Memb Super, 15(1), 11-17. doi: 10.1016/s0753-9053(96)80019-6.

21. El-Adl, W. (2007 Dec). Two-stage double-level rotational osteotomy in the treatment of congenital radioulnar synostosis. Acta Orthop Belg, 73(6), 704-709

22. Fujimoto, M., Kato, H., \& Minami, A. (2005 Sep-Oct). Rotational osteotomy at the diaphysis of the radius in the treatment of congenital radioulnar synostosis. J Pediatr Orthop, 25(5), 676-679. doi: 10.1097/01.bpo.0000161833.57409.bb.

23. Hung, N. N. (2008 Dec). Derotational osteotomy of the proximal radius and the distal ulna for congenital radioulnar synostosis. $J$ Child Orthop, 2(6), 481489. doi: 10.1007/s11832-008-0146-5.. Epub 2008 Nov 18

24. Murase, T., Tada, K., Yoshida, T., \& Moritomo, H.. Derotational osteotomy at the shafts of the radius and ulna for congenital radioulnar synostosis.J Hand Surg Am. 2003Jan;28(1):133-7. doi: 10.1053/jhsu.2003.50010

25. Ramachandran, M., Lau, K., \& Jones, D. H. (2005 Oct;87(10):1406-10). Rotational osteotomies for congenital radioulnar synostosis. J Bone Joint Surg Br. doi: 10.1302/0301-620X.87B10.16445. Available from https://doi.org/10.1302/0301-620X.87B10.16445

26. Yammine, K., Salon, A., \& Pouliquen, J. C. (1998). Congenital radioulnar synostosis. Study of a series of 37 children and adolescents. Chir Main, 17(4), 300-308. https://doi.org/10.1016/S0753-9053(98)80029-X

27. Pasupathy, B., Tholgappiyan, T., \& Sureshbabu, M. (2018). Congenital radio ulnar synostosis, analysis of functional outcome using double rotation osteotomy and osteotomy at synostosis site. International Journal of Orthopaedics Sciences, 4(2k), 755-759.

https://doi.org/10.22271/ortho.2018.v4.i2k.110

28. Farzan, M., Kh, D., Mortazavi, S. M., \& Espander, R. (2002). Congenital radioulnar synostosis: A report of 11 cases and review of literature. Acta Medica Iranica, 126-131. https://doi.org/10.11604/pamj-cm.2019.1.31.20680

29. Mohammed, T. C., Hicham, A., Karima, A., Lamyae, C., \& Moulay-Abderahman, A.. Outcomes of derotation osteotomy at synostosis site for congenital radioulnar synostosis.PAMJ-Clinical Medicine. 2019 Nov29;1(31). https://doi.org/10.11604/pamj-cm.2019.1.31.20680

30. ElSayed, S. A. (2014). Derotation osteotomy for congenital radioulnar synostosis. The Egyptian Orthopaedic Journal. Apr 1;49(2):92. https://doi.org/10.4103/1110-1148.145301

31. Dogra, B. B., Singh, M., \& Malik, A. (2003 Jan). Congenital proximal radioulnar synostosis. Indian Journal of Plastic Surgery, 36(1), 36-38

32. Jia, Y., Geng, C., Song, Z., Lv, S., \& Dai, B. (2020 Apr). Congenital unilateral proximal radioulnar synostosis: A surgical case report. Medicine (Baltimore). ;99(16):e19782. doi: 10.1097/MD.0000000000019782

33. Siemianowicz, A., Wawrzynek, W., \& Besler, K. (2010 Oct). Congenital radioulnar synostosis - case report. Pol J Radiol, 75(4), 51-54

34. Seitz, W. H. Jr., Gordon, T. L., \& Konsens, R. M. (1990 Feb). Pediatric update \#11. Congenital radioulnar synostosis. A new technique for derotational osteotomy. Orthop Rev, 19(2), 192-196

35. Bakkaly, A., Ghordaf, I., Bouljrouf, J., Amrani, A., Dendane, A., Fellous, S., et al. (2017). Surgical treatment of congenital radioulnar synostosis in children: A case report. Int J Surg Med [Internet]. ;1. doi: 10.5455/ijsm.SURGICAL-TREATMENT-OF-CONGENITAL-RADIOULNAR-SYNOSTOSIS

36. Miura, T., Nakamura, R., Suzuki, M., \& Kanie, J. (1984 Jun). Congenital radio-ulnar synostosis. J Hand Surg Br, 9(2), 153-155

37. Andrisano, A., Soncini, G., Calderoni, P. P., \& Bungaro, P. (1994). Congenital proximal radioulnar synostosis: Surgical treatment. J Pediatr Orthop Part $B$ [Internet], 3(1), 102-106

38. Wilkie, D. P. D. (1914). Congenital radioulnar synostosis. Br J Surg, 1, 366-375. https://doi.org/https://doi.org/10.1002/bjs.1800010305.

39. Hardy, B. T., Glowczewskie, F. Jr., \& Wright, T. W. (2011 May). Vascular anatomy of the proximal ulna. J Hand Surg Am, 36(5), 808-810. doi: 10.1016/j.jhsa.2011.02.011.. Epub 2011 Apr 12

40. Dalton, J. F. 4th, Manske, P. R., Walker, J. C., \& Goldfarb, C. A. (2006 Jul-Aug). Ulnar nonunion after osteoclasis for rotational deformities of the forearm. J Hand Surg Am, 31(6), 973-978. doi: 10.1016/j.jhsa.2006.03.006.

\section{Tables}

Table 1. Summary of outcomes in corrective derotation osteotomies in congenital radioulnar synostosis of the forearm in children. 


\begin{tabular}{|c|c|c|c|c|c|c|c|c|c|}
\hline $\begin{array}{l}\text { Author/Study } \\
\text { name }\end{array}$ & $\begin{array}{l}\text { Number } \\
\text { of } \\
\text { forearms } \\
\text { operated } \\
\text { (Sample } \\
\text { size) }\end{array}$ & $\begin{array}{l}\text { Mean age } \\
\text { in years } \\
\text { (range) }\end{array}$ & $\begin{array}{l}\text { Radiological } \\
\text { classification } \\
\text { schemes } \\
\text { Type } \\
\text { I/II/III/IV }\end{array}$ & $\begin{array}{l}\text { Type of } \\
\text { derotation } \\
\text { osteotomy } \\
\text { (surgical } \\
\text { procedure) }\end{array}$ & $\begin{array}{l}\text { Method of } \\
\text { immobilisation } \\
\text { Implant/ } \\
\text { plaster of Paris } \\
\text { (POP). }\end{array}$ & $\begin{array}{l}\text { Mean follow- } \\
\text { up in months. }\end{array}$ & $\begin{array}{l}\text { Mean time } \\
\text { to union } \\
\text { at the } \\
\text { osteotomy } \\
\text { site } \\
\text { (weeks) }\end{array}$ & $\begin{array}{l}\text { Meana (Range) } \\
\text { preoperative } \\
\text { rotation } \\
\text { deformity in } \\
\text { degrees. }\end{array}$ & $\begin{array}{l}\text { Mean }^{a} \\
\text { (range) } \\
\text { rotation } \\
\text { degrees }\end{array}$ \\
\hline
\end{tabular}

\begin{tabular}{|c|c|c|c|c|c|c|c|c|c|}
\hline $\begin{array}{l}\text { Bishay SN et } \\
\text { al. (19) }\end{array}$ & 14 & $\begin{array}{l}5.2 \\
(4.9-6.5)\end{array}$ & $0 / 4 / 10 / 0^{b}$ & $\begin{array}{l}\text { One stage } \\
\text { both bones of } \\
\text { forearm } \\
\text { double-level } \\
\text { osteotomy } \\
\text { (proximal ulna } \\
\text { and distal } \\
\text { radius). }\end{array}$ & $\begin{array}{l}\text { Implant (Long } \\
\text { intramedullary } \\
\text { wire) }\end{array}$ & $\begin{array}{l}30.4 \\
\text { (24 to } 36)\end{array}$ & $\begin{array}{l}6.9 \\
\text { (6 to } 9)\end{array}$ & $\begin{array}{l}+70.7 \\
\text { Range (+60 to } \\
+85)\end{array}$ & $\begin{array}{l}\begin{array}{l}\text { 1. }+20 t \\
\text { domina }\end{array} \\
\text { 2. - } 20 \mathrm{n} \\
\text { forearm } \\
\text { Range ( }\end{array}$ \\
\hline
\end{tabular}

\begin{tabular}{|c|c|c|c|c|c|c|c|c|}
\hline $\begin{array}{l}\text { Castello JR et } \\
\text { al. (20) }\end{array}$ & 4 & $\begin{array}{l}7.4 \\
(4-9)\end{array}$ & $0 / 0 / 3 / 0^{b}$ & $\begin{array}{l}\text { Osteotomy at } \\
\text { the synostosis } \\
\text { site } \\
\text { proximally. }\end{array}$ & $\begin{array}{l}\text { Implant (Cross } \\
\mathrm{K} \text { wires) }\end{array}$ & 96 (36 to 120$)$ & $\begin{array}{l}\text { Not } \\
\text { reported }\end{array}$ & $\begin{array}{l}>+80 \\
(+80 \text { to }+100)\end{array}$ \\
\hline
\end{tabular}

\begin{tabular}{|c|c|c|c|c|c|c|c|c|c|}
\hline $\begin{array}{l}\text { El -Adl et al. } \\
(21)\end{array}$ & 11 & $\begin{array}{l}5.5 \\
(3.75- \\
8.25)\end{array}$ & $0 / 2 / 9 / 0^{b}$ & $\begin{array}{l}\text { Both bones of } \\
\text { forearm } \\
\text { double-level } \\
\text { osteotomy } \\
\text { (Proximal } \\
\text { ulna and the } \\
\text { distal radius). }\end{array}$ & $\begin{array}{l}\text { Plaster of } \\
\text { Paris splint }\end{array}$ & 26.4 (13 to 38$)$ & $\begin{array}{l}5.9 \\
\text { (5 to } 7 \text { ) }\end{array}$ & $\begin{array}{l}+76 \\
(+60 \text { to }+85)\end{array}$ & $\begin{array}{l}\text { 1. }+20 \text { - } \\
\text { domina } \\
\text { 2. }-20= \\
\text { domina }\end{array}$ \\
\hline
\end{tabular}




\begin{tabular}{|c|c|c|c|c|c|c|c|c|c|}
\hline $\begin{array}{l}\text { ElSayed et al. } \\
(30)\end{array}$ & 5 & $\begin{array}{l}10 \\
(5-22)\end{array}$ & $0 / 0 / 5 / 0^{b}$ & $\begin{array}{l}\text { Osteotomy at } \\
\text { the synostosis } \\
\text { site. }\end{array}$ & $\begin{array}{l}\text { Implant } \\
\text { (Dynamic } \\
\text { compression } \\
\text { plate) }\end{array}$ & $23(8$ to 52$)$ & $\begin{array}{l}7 \\
\text { (5 to } 12)\end{array}$ & $\begin{array}{l}+96 \\
\text { Range (+60 to } \\
+180)\end{array}$ & $\begin{array}{l}\text { 1. Mear } \\
\text { 2. } 0=4 \\
\text { 3. }+25=\end{array}$ \\
\hline
\end{tabular}

\begin{tabular}{|c|c|c|c|c|c|c|c|c|c|}
\hline $\begin{array}{l}\text { Farzan M et al. } \\
(28)\end{array}$ & 3 & $\begin{array}{l}4.5 \\
(3-6)\end{array}$ & $3 / 0^{c}$ & $\begin{array}{l}\text { One bone } \\
\text { forearm } \\
\text { Proximal Ulna } \\
\text { Osteotomy } \\
\text { distal to } \\
\text { fusion mass. }\end{array}$ & $\begin{array}{l}\text { Implant (Cross } \\
\text { K wires) }\end{array}$ & $\begin{array}{l}41 \\
\text { (12 to } 72 \text { ) }\end{array}$ & $\begin{array}{l}\text { Not } \\
\text { reported }\end{array}$ & $\begin{array}{l}+113 \\
(+110 \text { to }+120)\end{array}$ & $\begin{array}{l}-13.3 \\
\text { Range }\end{array}$ \\
\hline \multirow{2}{*}{$\begin{array}{l}\text { Fujimoto } M \text { et } \\
\text { al. } \\
(22)\end{array}$} & \multirow[t]{2}{*}{4} & 4.42 & \multirow[t]{2}{*}{$0 / 0 / 4 / 0^{b}$} & \multirow{2}{*}{$\begin{array}{l}\text { One bone } \\
\text { forearm distal } \\
\text { radius drill } \\
\text { assisted } \\
\text { osteotomy \& } \\
\text { osteoclasis. }\end{array}$} & \multirow{2}{*}{$\begin{array}{l}\text { Plaster of } \\
\text { Paris } \\
\text { (Long arm } \\
\text { cast) }\end{array}$} & 21 & \multirow[t]{2}{*}{8 (6 to 9$)$} & +76 & Mean $=$ \\
\hline & & $\begin{array}{l}(3.92- \\
4.92)\end{array}$ & & & & (12 to 36$)$ & & $\begin{array}{l}\text { Range (+70 } \\
\text { to+85) }\end{array}$ & $\begin{array}{l}\text { 1. }(+10 \\
3 \text { forear } \\
\text { 2. }-10=\end{array}$ \\
\hline
\end{tabular}

\begin{tabular}{|c|c|c|c|c|c|c|c|c|c|}
\hline \multirow{4}{*}{$\begin{array}{l}\text { Green WT et al. } \\
\text { (6) }\end{array}$} & \multirow[t]{4}{*}{12} & 8 & \multirow[t]{4}{*}{ NA } & \multirow{4}{*}{$\begin{array}{l}\text { Osteotomy } \\
\text { through the } \\
\text { synostosis } \\
\text { site. }\end{array}$} & \multirow{4}{*}{$\begin{array}{l}\text { Implant (Cross } \\
\text { K wires) }\end{array}$} & \multirow{4}{*}{$\begin{array}{l}192(120 \text { to } \\
306)\end{array}$} & \multirow{4}{*}{$\begin{array}{l}\text { Not } \\
\text { reported }\end{array}$} & +76 & 1. $+14=$ \\
\hline & & \multirow[t]{3}{*}{$\begin{array}{l}(3.5- \\
17.75)\end{array}$} & & & & & & Range ( +30 to & 2. $-20=$ \\
\hline & & & & & & & & & 3. $0=2$ \\
\hline & & & & & & & & & Range ( \\
\hline
\end{tabular}




\begin{tabular}{|c|c|c|c|c|c|c|c|c|c|}
\hline \multirow{4}{*}{$\begin{array}{l}\text { Hung NN et al. } \\
\text { (23) }\end{array}$} & \multirow[t]{4}{*}{52} & 6.25 & \multirow[t]{4}{*}{$6 / 46^{d}$} & \multirow{4}{*}{$\begin{array}{l}\text { Both bones of } \\
\text { forearm } \\
\text { double-level } \\
\text { osteotomy } \\
\text { involving } \\
\text { resection of } \\
\text { the proximal } \\
\text { radius and the } \\
\text { distal ulna to } \\
\text { remove a } \\
\text { segment of } \\
\text { bone. }\end{array}$} & \multirow{4}{*}{$\begin{array}{l}\text { Implant (Long } \\
\text { intramedullary } \\
\text { K wires) }\end{array}$} & \multirow[t]{4}{*}{$64(30$ to 129$)$} & \multirow{4}{*}{$\begin{array}{l}7.2(6.6 \text { to } \\
7.4)\end{array}$} & \multirow{3}{*}{$\begin{array}{l}\text { 1. } 82 \text { deg- } \\
\text { dominant } \\
\text { hand }=24 \\
\text { 2. } 74 \text { deg-non- } \\
\text { dominant } \\
\text { hand }=28\end{array}$} & 1.+6-do \\
\hline & & $\begin{array}{l}(3.75- \\
9.91)\end{array}$ & & & & & & & $\begin{array}{l}2 .+10-n \\
\text { hand }\end{array}$ \\
\hline & & & & & & & & & 3. Rang \\
\hline & & & & & & & & $\begin{array}{l}\text { 3. Range (65- } \\
85)\end{array}$ & \\
\hline
\end{tabular}

\begin{tabular}{|c|c|c|c|c|c|c|c|c|c|}
\hline $\begin{array}{l}\text { Hwang JH et } \\
\text { al. (11) }\end{array}$ & 28 & $\begin{array}{l}7 \\
(4-16)\end{array}$ & $4 / 5 / 19 / 0^{b}$ & $\begin{array}{l}\text { One-stage } \\
\text { both bone } \\
\text { forearm } \\
\text { derotation } \\
\text { osteotomy of } \\
\text { the proximal } \\
\text { ulna and } \\
\text { distal radius } \\
\text { with } \\
\text { segmental } \\
\text { bone } \\
\text { resection }\end{array}$ & $\begin{array}{l}\text { Implant } \\
\text { (Intramedullary } \\
\text { flexible nail in } \\
\text { ulna) }\end{array}$ & $33(12$ to 72$)$ & 7 (6 to 8$)$ & $\begin{array}{l}+47 \\
\text { Range (30 to } \\
65)\end{array}$ & $\begin{array}{l}-27 \\
\text { Range ( }\end{array}$ \\
\hline
\end{tabular}

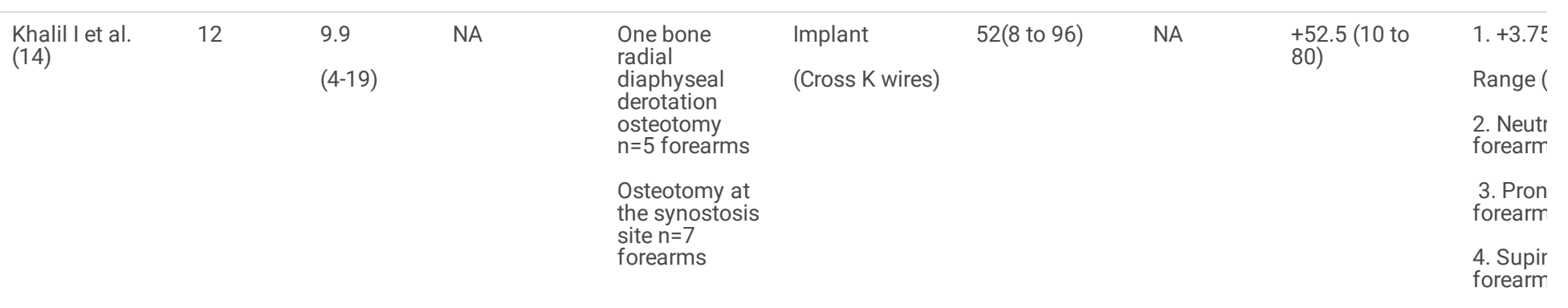




\begin{tabular}{|c|c|c|c|c|c|c|c|c|c|}
\hline $\begin{array}{l}\text { Lin } \mathrm{HH} \text { et } \\
\text { al. (13) }\end{array}$ & 12 & $\begin{array}{l}5.92 \\
(2-14.3)\end{array}$ & NA & $\begin{array}{l}\text { Both bones } \\
\text { drill assisted } \\
\text { osteotomy of } \\
\text { Proximal ulna } \\
\text { and distal } \\
\text { radius }\end{array}$ & $\begin{array}{l}\text { Plaster of } \\
\text { Paris (Long } \\
\text { arm cast) }\end{array}$ & $\begin{array}{l}96.12 \text { (20 to } \\
174)\end{array}$ & 6 & $\begin{array}{l}\text { 1. }+76=14 \\
\text { forearms } \\
\begin{array}{l}\text { 2. }-68=11 \\
\text { forearms }\end{array}\end{array}$ & $\begin{array}{l}\text { 1. }-5=1 \\
\text { 2. } 0=1\end{array}$ \\
\hline
\end{tabular}

\begin{tabular}{|c|c|c|c|c|c|c|c|c|c|}
\hline $\begin{array}{l}\text { Mohammad } \\
\text { TC et al. (29) }\end{array}$ & 11 & $\begin{array}{l}5 \\
(3-10)\end{array}$ & $0 / 1 / 9 / 1^{b}$ & $\begin{array}{l}\text { Osteotomy at } \\
\text { the } \\
\text { Synostosis } \\
\text { site. }\end{array}$ & $\begin{array}{l}\text { Implant (Cross } \\
\text { K wire) }\end{array}$ & $\begin{array}{l}50.4(12 \text { to } \\
120)\end{array}$ & $\begin{array}{l}12(8 \text { to } \\
16)\end{array}$ & $\begin{array}{l}+62 \\
\text { Range (+45 to } \\
+85)\end{array}$ & $\begin{array}{l}\text { Derotat } \\
\text { or }+30 \text {. }\end{array}$ \\
\hline
\end{tabular}

\begin{tabular}{|c|c|c|c|c|c|c|c|c|c|}
\hline $\begin{array}{l}\text { Murase T et al. } \\
(24)\end{array}$ & 4 & $\begin{array}{l}3.9 \\
(2.2-5)\end{array}$ & $0 / 0 / 4 / 0^{b}$ & $\begin{array}{l}\text { Open } \\
\text { osteotomy } \\
\text { and } \\
\text { intramedullary } \\
\text { K wire fixation } \\
\text { followed by } \\
\text { derotation } \\
\text { (proximal ulna } \\
\text { and distal } \\
\text { radius) }\end{array}$ & $\begin{array}{l}\text { Implant } \\
\text { (intramedullary } \\
\text { K wire) }\end{array}$ & $45.8(14$ to 73$)$ & $\begin{array}{l}7.5 \text { (6.9 to } \\
7.9)\end{array}$ & $\begin{array}{l}+78 \\
\text { Range }(+70 \\
\text { to+ 80) }\end{array}$ & $\begin{array}{l}+7.5 \\
\text { Range ( }\end{array}$ \\
\hline $\begin{array}{l}\text { Ogino T et al. } \\
\text { (9) }\end{array}$ & 13 & $\begin{array}{l}7 \\
(4-13)\end{array}$ & NA & $\begin{array}{l}\text { Osteotomy at } \\
\text { the } \\
\text { Synostosis } \\
\text { site. }\end{array}$ & $\begin{array}{l}\text { Implant } \\
\text { (Tension band } \\
\text { fixation) }\end{array}$ & 48 & NA & $\begin{array}{l}+65.8 \\
\text { Range (+30 to } \\
+110)\end{array}$ & $\begin{array}{l}-4.2 \\
\text { Range ( }\end{array}$ \\
\hline
\end{tabular}

\begin{tabular}{|c|c|c|c|c|c|c|c|c|c|}
\hline $\begin{array}{l}\text { Pasupathy D et } \\
\text { al. (27) }\end{array}$ & 20 & $\begin{array}{l}4 \\
(2-9)\end{array}$ & NA & $\begin{array}{l}\text { 1. Osteotomy } \\
\text { at the } \\
\text { Synostosis } \\
\text { site } n=10 \\
\text { patients } \\
\text { 2. Both bones } \\
\text { of forearm } \\
\text { double-level } \\
\text { osteotomy of } \\
\text { proximal ulna } \\
\text { and distal } \\
\text { radius. } n=10 \\
\text { patients. }\end{array}$ & $\begin{array}{l}\text { Heterogenous } \\
\text { ) }\end{array}$ & $26.4(7$ to 48$)$ & $\begin{array}{l}\text { Not } \\
\text { reported }\end{array}$ & $\begin{array}{l}+72.25 \\
\text { Range (55 to } \\
85)\end{array}$ & $\begin{array}{l}-22 \\
\text { Range ( }\end{array}$ \\
\hline Pei X et al. & 36 & $4.87 \pm 3.06$ & $0 / 9 / 23 / 4^{b}$ & $\begin{array}{l}\text { Osteotomy at } \\
\text { the }\end{array}$ & $\begin{array}{l}\text { Implant (plate } \\
\text { fixation) }\end{array}$ & $\begin{array}{l}55.19 \pm 27.1(24 \\
\text { to } 123)\end{array}$ & 8 & $+62.92 \pm 7.11$ & $-7.94 \pm$ \\
\hline
\end{tabular}


Synostosis

osteotomy \&

ulnar fixation

with $2.7 \mathrm{~mm}$

locking plate
Range ( +55 to

+80 ) 


\begin{tabular}{|c|c|c|c|c|c|c|c|c|c|}
\hline $\begin{array}{l}\text { Ramachandran } \\
\text { M et al. } \\
(25)\end{array}$ & 6 & $\begin{array}{l}4.9 \\
(3.5-8.25)\end{array}$ & $0 / 1 / 5 / 0^{b}$ & $\begin{array}{l}\text { Both bones of } \\
\text { forearm } \\
\text { double-level } \\
\text { osteotomy of } \\
\text { proximal ulna } \\
\text { and distal } \\
\text { radius. }\end{array}$ & $\begin{array}{l}\text { Implant } \\
\text { (Intramedullary } \\
\text { wire) }\end{array}$ & $29(18$ to 43$)$ & $\begin{array}{l}6.3 \text { (6 to } \\
8)\end{array}$ & $\begin{array}{l}+68 \\
\text { Range }(+40 \\
\text { to+ } 80)\end{array}$ & -10 \\
\hline
\end{tabular}

\begin{tabular}{|c|c|c|c|c|c|c|c|c|c|}
\hline $\begin{array}{l}\text { Satake H et al. } \\
\text { (16) }\end{array}$ & 12 & $\begin{array}{l}6.4 \\
(4.5-10)\end{array}$ & NA & $\begin{array}{l}\text { One bone } \\
\text { derotation } \\
\text { osteotomy of } \\
\text { the Radius } \\
\text { shaft }\end{array}$ & $\begin{array}{l}\text { Plaster of } \\
\text { Paris (Long } \\
\text { arm cast) }\end{array}$ & $\begin{array}{l}163.2(120 \text { to } \\
228)\end{array}$ & $8.7(7-12)$ & $\begin{array}{l}+51.3 \\
\text { Range (+30 to } \\
+90)\end{array}$ & $\begin{array}{l}\text { 1. }-4.2= \\
\text { Range ( } \\
\text { 2. }-20=\text { ? }\end{array}$ \\
\hline
\end{tabular}

\begin{tabular}{|c|c|c|c|c|c|c|c|c|c|}
\hline $\begin{array}{l}\text { Shingade VU et } \\
\text { al. } \\
\text { (2) }\end{array}$ & 30 & $\begin{array}{l}8.6 \pm 3.7 \\
(2-15)\end{array}$ & NA & $\begin{array}{l}\text { Both bones of } \\
\text { forearm } \\
\text { double-level } \\
\text { osteotomy of } \\
\text { proximal ulna } \\
\text { and distal } \\
\text { radius. }\end{array}$ & $\begin{array}{l}\text { Plaster of } \\
\text { Paris } \\
\text { (Long arm cast } \\
\text { x 5wks) }\end{array}$ & $\begin{array}{l}54 \pm 13(36 \text { to } \\
84)\end{array}$ & 5 & $\begin{array}{l}+56.3 \pm 13.7 \\
\text { Range }(+30 \text { to } \\
+86)\end{array}$ & $\begin{array}{l}-27.2 \pm 4 \\
\text { Range ( }\end{array}$ \\
\hline
\end{tabular}




\begin{tabular}{|c|c|c|c|c|c|c|c|c|c|}
\hline $\begin{array}{l}\text { Simcock X et } \\
\text { al. } \\
\text { (4) }\end{array}$ & 31 & $\begin{array}{l}6.8 \pm 3.7 \\
(3-18.8)\end{array}$ & $0 / 2 / 27 / 0^{b}$ & $\begin{array}{l}\text { Osteotomy at } \\
\text { the synostosis } \\
\text { site. }\end{array}$ & $\begin{array}{l}\text { Implant } \\
\text { (Oblique K } \\
\text { wires) }\end{array}$ & $\begin{array}{l}46 \pm 46(6 \text { to } \\
148)\end{array}$ & 8 & $\begin{array}{l}85 \pm 12.9 \\
\text { Range (+60 to } \\
+100)\end{array}$ & $\begin{array}{l}8 \pm 8.7 \\
\text { Range ( }\end{array}$ \\
\hline
\end{tabular}

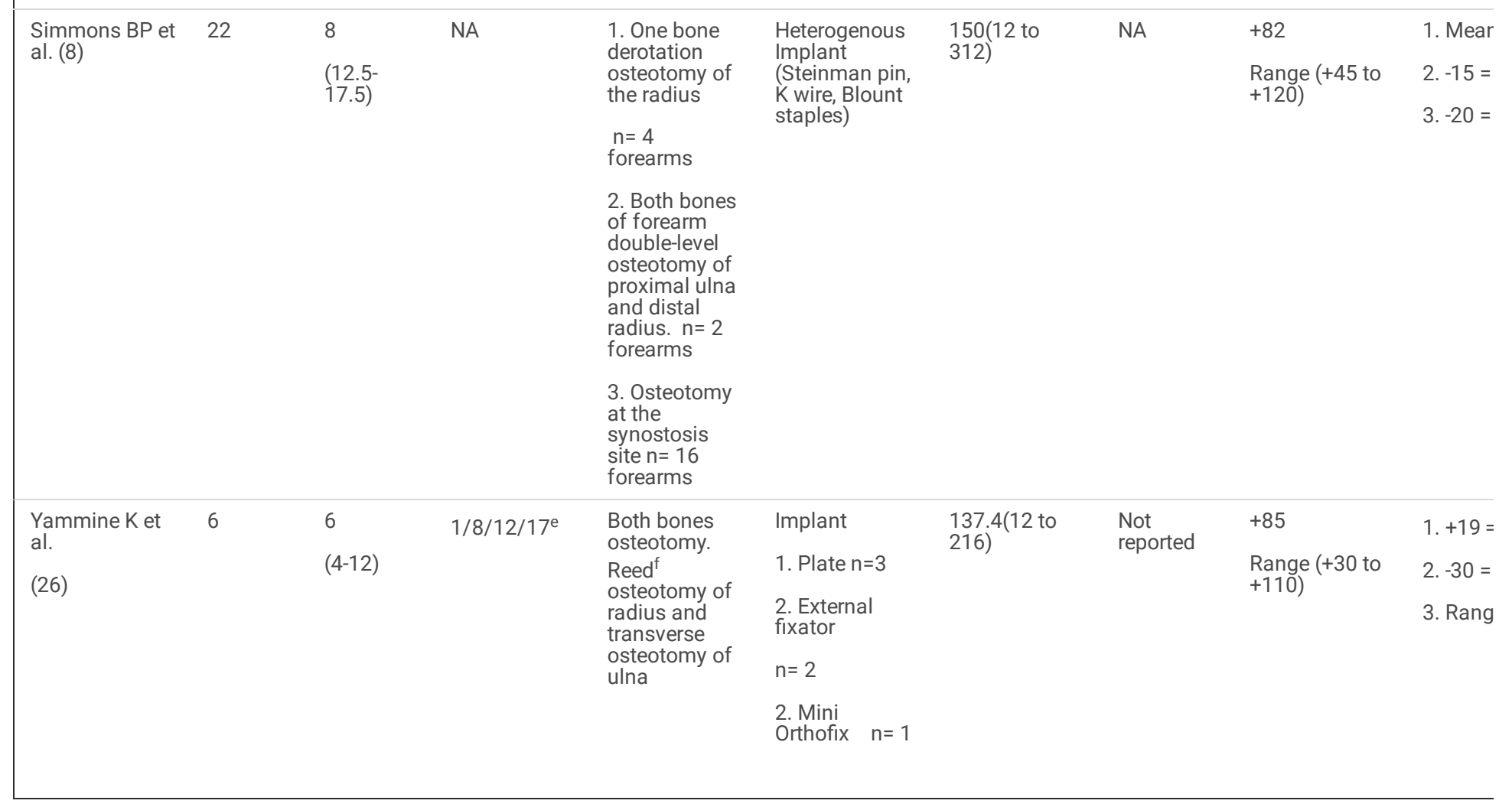

\footnotetext{
a Positive and negative integers against the study represent pronation and supination respectively.

b Cleary and Omer classification

c Wilkie classification

d Tachdjian's criteria type I/II

e Radiological classification by Yammine et al.7 patients were operated of 38 in the series.

$\mathrm{f}$ Reed osteotomy being a vertical osteotomy along the axis of radius.
}

Table 2. Risk of bias assessment for the included studies 


\begin{tabular}{|c|c|c|c|}
\hline Author/Study name & Design/level of evidence & $\begin{array}{l}\text { The National Institutes of Health (NIH) quality assessment tool for } \\
\text { case-series (Interventional)[20] }\end{array}$ & $\begin{array}{c}\text { Modified Coleman } \\
\text { Methodology Score } \\
\text { [19] }\end{array}$ \\
\hline $\begin{array}{l}\text { Bishay SN et al. } \\
\text { (19) }\end{array}$ & $\begin{array}{l}\text { Prospective case } \\
\text { series/IV }\end{array}$ & Fair & 50 \\
\hline $\begin{array}{l}\text { Castello JR et al. } \\
(20)\end{array}$ & $\begin{array}{l}\text { Prospective case } \\
\text { series/IV }\end{array}$ & Fair & 41 \\
\hline El -Adl et al. (21) & $\begin{array}{l}\text { Prospective case } \\
\text { series/IV }\end{array}$ & Fair & 50 \\
\hline ElSayed et al. (30) & $\begin{array}{l}\text { Case series } \\
\text { unspecified/IV }\end{array}$ & Fair & 30 \\
\hline Farzan M et al. (28) & $\begin{array}{l}\text { Retrospective Case } \\
\text { series/IV }\end{array}$ & Fair & 33 \\
\hline $\begin{array}{l}\text { Fujimoto } \mathrm{M} \text { et al. } \\
(22)\end{array}$ & $\begin{array}{l}\text { Retrospective Case } \\
\text { series/IV }\end{array}$ & Fair & 40 \\
\hline Green WT et al. (6) & $\begin{array}{l}\text { Case series } \\
\text { unspecified/IV. }\end{array}$ & Fair & 41 \\
\hline Horii E et al. (7) & $\begin{array}{l}\text { Cohort study not } \\
\text { specified/IV. }\end{array}$ & Fair & 42 \\
\hline Hung NN et al. (23) & $\begin{array}{l}\text { Prospective Cohort } \\
\text { study/IV }\end{array}$ & Good & 57 \\
\hline $\begin{array}{l}\text { Hwang JH et al. } \\
(11)\end{array}$ & $\begin{array}{l}\text { Retrospective cohort } \\
\text { study/IV }\end{array}$ & Good & 43 \\
\hline Khalil I et al. (14) & $\begin{array}{l}\text { Retrospective Case } \\
\text { series/IV }\end{array}$ & Poor & 26 \\
\hline Lin HH et al. (13) & $\begin{array}{l}\text { Retrospective Case } \\
\text { series/IV }\end{array}$ & Poor & 41 \\
\hline $\begin{array}{l}\text { Mohammad TC et } \\
\text { al. (29) }\end{array}$ & $\begin{array}{l}\text { Retrospective Case } \\
\text { series/IV }\end{array}$ & Fair & 40 \\
\hline Murase T et al. (24) & $\begin{array}{l}\text { Retrospective Case series } \\
\text { /IV }\end{array}$ & Fair & 43 \\
\hline Ogino T et al. (9) & $\begin{array}{l}\text { Retrospective Case } \\
\text { series/IV }\end{array}$ & Fair & 38 \\
\hline $\begin{array}{l}\text { Pasupathy D et al. } \\
\text { (27) }\end{array}$ & $\begin{array}{l}\text { Retrospective Case } \\
\text { series/IV }\end{array}$ & Fair & 25 \\
\hline Pei $X$ et al. (10) & $\begin{array}{l}\text { Retrospective Case } \\
\text { series/IV }\end{array}$ & Good & 46 \\
\hline $\begin{array}{l}\text { Ramachandran } \\
\text { M et al. (25) }\end{array}$ & $\begin{array}{l}\text { Retrospective Case } \\
\text { series/IV }\end{array}$ & Poor & 40 \\
\hline Satake H et al. (16) & $\begin{array}{l}\text { Retrospective cohort } \\
\text { series/IV }\end{array}$ & Fair & 48 \\
\hline $\begin{array}{l}\text { Shingade VU et al. } \\
(2)\end{array}$ & $\begin{array}{l}\text { Retrospective } \\
\text { Comparative study/III }\end{array}$ & Good & 56 \\
\hline Simcock X et al. (4) & $\begin{array}{l}\text { Retrospective Cohort } \\
\text { study/IV }\end{array}$ & Fair & 42 \\
\hline $\begin{array}{l}\text { Simmons BP et al. } \\
(8)\end{array}$ & Retrospective Case series & Poor & 26 \\
\hline \multirow{2}{*}{$\begin{array}{l}\text { Yammine } \mathrm{K} \text { et al. } \\
(26)\end{array}$} & Retrospective & Fair & 31 \\
\hline & Case series & & \\
\hline
\end{tabular}

Table 3. Radiological classification schemes for Congenital radioulnar synostosis in children 


\begin{tabular}{|c|c|c|c|c|}
\hline Author/Study & I & II & III & IV \\
\hline Wilkie. [38] & $\begin{array}{l}\text { There is lack of proximal radius, bony fusion } \\
\text { for } 3-6 \mathrm{~cm} \text {, and medullary canal of radius and } \\
\text { ulna is connected. }\end{array}$ & $\begin{array}{l}\text { Normal radius, and the synostosis } \\
\text { is located just distal to proximal } \\
\text { radial } \\
\text { epiphysis, so the radial head is } \\
\text { dislocated anteriorly or posteriorly }\end{array}$ & & \\
\hline $\begin{array}{l}\text { Tachdjian's } \\
\text { criteria. [23] }\end{array}$ & $\begin{array}{l}\text { Radial head may be fused to the ulna, or it } \\
\text { may be completely absent (headless type) }\end{array}$ & $\begin{array}{l}\text { The radial head is malformed and } \\
\text { possibly dislocated }\end{array}$ & & \\
\hline $\begin{array}{l}\text { Cleary and } \\
\text { Omer. [2] }\end{array}$ & $\begin{array}{l}\text { Synostosis not involving } \\
\text { bone and associated with a reduced normal } \\
\text { appearing } \\
\text { radial head }\end{array}$ & $\begin{array}{l}\text { Visible osseous synostosis but } \\
\text { associated with otherwise normal } \\
\text { findings }\end{array}$ & $\begin{array}{l}\text { Osseous synostosis with a } \\
\text { hypoplastic and } \\
\text { posteriorly } \\
\text { dislocated radial head }\end{array}$ & $\begin{array}{l}\text { Short osseous } \\
\text { synostosis with } \\
\text { an anteriorly } \\
\text { dislocated radial } \\
\text { head } \\
\text { usually } \\
\text { mushroom- } \\
\text { shaped }\end{array}$ \\
\hline $\begin{array}{l}\text { Andrisano et } \\
\text { al. [37] }\end{array}$ & $\begin{array}{l}\text { Morphology of elbow well preserved, the } \\
\text { ossification nucleus of radial head evident } \\
\text { and normal appearing radial head in adults }\end{array}$ & $\begin{array}{l}\text { Indistinguishable radial head from } \\
\text { the synostosis mass with proximal } \\
\text { ulna and a bowed radial shaft. }\end{array}$ & $\begin{array}{l}\text { Synostosis extending } \\
\text { beyond proximal ulna into } \\
\text { the interosseous } \\
\text { membrane }\end{array}$ & \\
\hline $\begin{array}{l}\text { Yammine et } \\
\text { al. [26] }\end{array}$ & Fibrous & Osseous & $\begin{array}{l}\text { Osseous with Dislocation } \\
\text { of the normal radial head }\end{array}$ & $\begin{array}{l}\text { Osseous with } \\
\text { dislocation of an } \\
\text { abnormal radial } \\
\text { head }\end{array}$ \\
\hline
\end{tabular}

Table 4. Summary of complications in corrective derotation osteotomy for congenital radioulnar synostosis. 


\begin{tabular}{|c|c|c|c|c|c|c|}
\hline Study name/ID & $\begin{array}{l}\text { Total number of } \\
\text { complications }\end{array}$ & Nerve Palsy ${ }^{a}$ & $\begin{array}{l}\text { Loss of } \\
\text { correction }\end{array}$ & Compartment syndrome & $\begin{array}{l}\text { Nonunion/ Delayed } \\
\text { union/Malunion/Crossunion }\end{array}$ & Infection \\
\hline $\begin{array}{l}\text { Farzan M et al. } \\
\text { (28) }\end{array}$ & 1 & & & 1-Reversible & & \\
\hline $\begin{array}{l}\text { Fujimoto } M \text { et } \\
\text { al. (22) }\end{array}$ & 1 & & & & 1- Delayed union & \\
\hline $\begin{array}{l}\text { Green WT et al. } \\
\text { (6) }\end{array}$ & 1 & & & $\begin{array}{l}\text { 1- Functional recovery after } \\
\text { fasciotomy }\end{array}$ & & \\
\hline Horii E et al. (7) & 2 & & & & 2-Cross-union & \\
\hline $\begin{array}{l}\text { Hung NN et al. } \\
\text { (23) }\end{array}$ & 5 & & 5 & & & \\
\hline$\underset{(13)}{\operatorname{Lin} H ~ H ~ e t ~ a l . ~}$ & 9 & & 9 & & & \\
\hline $\begin{array}{l}\text { Mohammed TC } \\
\text { et al. (29) }\end{array}$ & 3 & & 1 & 1- Required fasciotomy & 1-nonunion & \\
\hline $\begin{array}{l}\text { Murase T et al. } \\
(24)\end{array}$ & 1 & & 1 & & & \\
\hline Ogino T et al. (9) & 2 & R-2 (Transient) & & & & \\
\hline $\begin{array}{l}\text { Pasupathy D et } \\
\text { al. (27) }\end{array}$ & 1 & & & & & 1 \\
\hline Pei $X$ et al. (10) & $3(9.7 \%)$ & $\begin{array}{l}\text { NS-2 } \\
\text { (Transient) }\end{array}$ & & $\begin{array}{l}\text { 1- Required FDL release after } \\
1 \text { year of osteotomy }\end{array}$ & & \\
\hline $\begin{array}{l}\text { Ramachandran } \\
\text { M et al. (25) }\end{array}$ & 1 & & & 1-Reversible & & \\
\hline $\begin{array}{l}\text { Shingade V et } \\
\text { al. (2) }\end{array}$ & 2 & & & & $\begin{array}{l}1 \text {-Delayed union, } 1 \text { - dorsal } \\
\text { angulation of radius }\end{array}$ & \\
\hline $\begin{array}{l}\text { Simcock X et al. } \\
(4)\end{array}$ & $4(12 \%)$ & $\begin{array}{l}\text { AIN -2 (Transient) } \\
\text { R-1 (Transient) }\end{array}$ & & 1-muscle herniation & & \\
\hline $\begin{array}{l}\text { Simmons BP et } \\
\text { al. (8) }\end{array}$ & $8(36 \%)$ & PIN - 1 Reversible & 3 & 4 & & $1^{\mathrm{c}}$ \\
\hline $\begin{array}{l}\text { Yammine } \mathrm{K} \text { et } \\
\text { al. (26) }\end{array}$ & 4 & & 3 & & 1 Delayed union & \\
\hline Total & 48 & 8 & 22 & 10 & 7 & \\
\hline
\end{tabular}
a. R (Radial nerve), NS (not specified), AIN (anterior interosseous nerve), PIN (posterior interosseous nerve).
b. Loss or correction greater than 5 degrees.
c. The complication of infection and implant failure and malunion occurred in one of the cases.

\section{Figures}




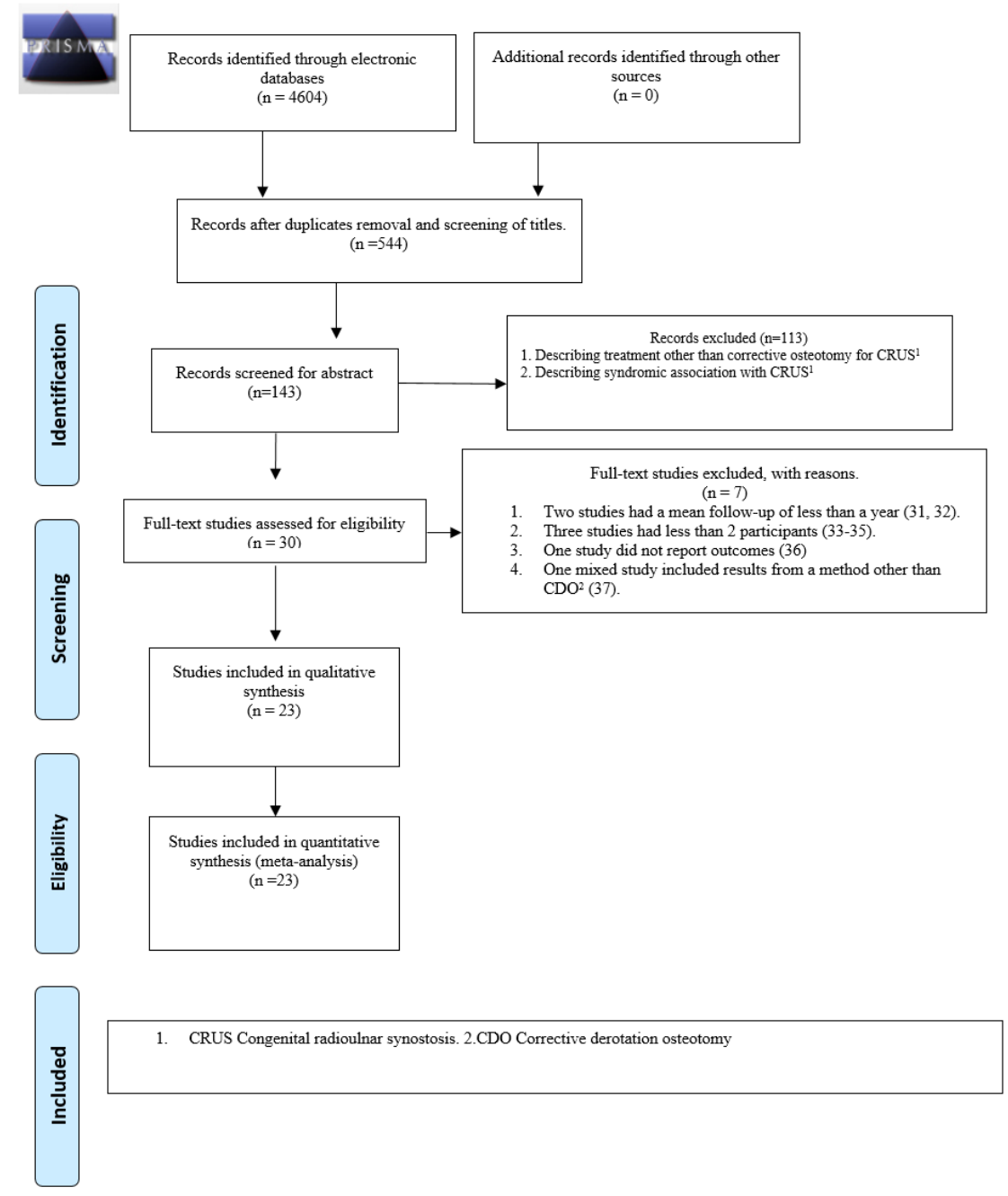

\section{Figure 1}

PRISMA Flow diagram

\section{Figure 2}

Risk of bias assessment on the National Institutes of Health $(\mathrm{NIH})$ quality assessment tool for case-series study (Interventional).

\section{Figure 3}

Forest plot for the pooled mean difference between the deformity before and after corrective derotation osteotomy. 

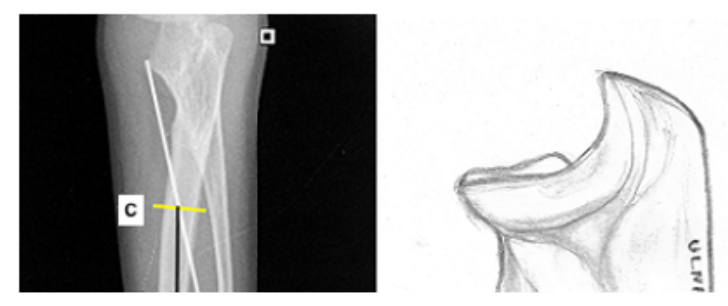

\section{Figure 4}

Representative case with radiographic planning and outcome of both bone corrective derotation osteotomy in Congenital radioulnar synostosis. Points of intersection $\mathrm{A}$ and $\mathrm{C}$ represent the site of osteotomy in forearm Point B represents the center of the broadest part of the interroseous membrane.

\section{Supplementary Files}

This is a list of supplementary files associated with this preprint. Click to download.

- Supplementarymaterialsubgroupanalysis.pdf

- appendix1.docx 